Hajdana Glomazićl

UDK: $371.687: 374.7$

$374.7: 654.197$

\title{
KARAKTERISTIKE ODRASLIH KAO FAKTORI PROCENE OBRAZOVNE FUNKCIJE TELEVIZIJE ${ }^{2}$
}

\section{- Sažetak -}

U ovom radu se pošlo od pretpostavke da obrazovna obeležja i televizijskomedijsko iskustvo odraslih određuju njihov odnos prema obrazovnoj funkciji televizije. Istraživanjem se želi dobiti odgovor na pitanje da li postoji, u kom stepenu i kakva je povezanost između određenih karakteristika ispitanika $i$ njihovog odnosa prema obrazovnoj funkciji televizije. Rezultati istraživanja su pokazali da nivo obrazovanja jeste faktor procene obrazovne funkcije televizije, te da pozitivan odnos prema obrazovnoj vrednosti televizijskih sadržaja raste sa višim nivoom obrazovanja. Pokazalo se $i$ da je nivo formalnog obrazovanja faktor od koga zavisi vrednovanje najpogodnijih formi za prikazivanje obrazovnih sadržaja. Takođe, rezultati sugerišu zaključak da je televizijsko-medijski status gledalaca značajan faktor procene obrazovne funkcije televizije.

Ključne reči: obrazovanje odraslih, televizija, mediji, medijsko obrazovanje.

1 Dr. Hajdana Glomazić, naučni saradnik u Institutu za kriminologiju i sociologiju, Beograd. E-mail: hajdana.ng@gmail.com.

2 Rad je deo neobjavljene doktorske disertacije „Odnos odraslih prema obrazovnoj i vaspitno-etičkoj funkciji televizije". 


\section{Uvod}

Popularizacijom medija i stvaranjem navike među ljudima da se od najranijeg detinjstva koriste medijima došlo je do pomeranja uloge socijalnih institucija koje se bave obrazovanjem i prenošenjem kulturnih vrednosti društva. Mediji, ne uvek ali često, imaju važnu ulogu u obrazovanju i popularizaciji kulturnih vrednosti i to mogu činiti na efektan, dramski način prezentovanja. Oni, pre svega, služe kao snažan kanal informisanja za širenje različitih znanja, a njihova prednost se ogleda u atraktivnosti načina prenošenja sadržaja. To se ponajpre odnosi na televiziju kao elektronski, audio-vizuelni medij sa najbrojnijim auditorijumom i sa najvećim uticajem. Istraživanja efekata televizije na odrasle gledaoce pokazala su da su formiranje ukusa, preferencija publike i obrazovnog uticaja prilično složeni procesi i da zavise od mnogobrojnih faktora.

\section{Faktori od kojih zavise medijski efekti na publiku}

Bez obzira na brojne kritike koje se medijima upućuju, u naučnim i istraživačkim krugovima postoji dilema o stvarnoj moći masovnih medija. Istraživači traže odgovor na pitanje da li je realno predstavljena moć medija ili se ona neopravdano mistifikuje i preuveličava. U tom smislu, aktualizuje se pitanje promene paradigme u proučavanju ponašanja publike, pa se od potcenjivačkog odnosa prema njenom ponašanju, koje datira od vremena kada se na nju gledalo kao na skupinu ljudi predvidivog ponašanja koja u proces medijske komunikacije ulazi bez ikakvih stavova, izgrađenog vrednosnog sistema, mišljenja, emocija i volje, fokus pažnje pomera ka njenim drugim karakteristikama.

Prva razmatranja efekata medija, radija i televizije, na publiku u najvećoj meri su se odnosila na model njihovog direktnog uticaja, što je kasnije pod uticajem podataka dobijenih različitim istraživanjima (Katz i Lazarsfeld, 1956) počelo da se dovodi u pitanje. Model narkodejstva televizije je shvatao javnost kao sasvim pasivne upijače onoga što im se medijski servira, a moć televizije je prikazana kao maltene neograničena u svom uticaju na mase. Ovaj model je prevaziđen upravo zahvaljujući dobijenim podacima iz istraživanja koja su imala cilj da utvrde stepen povezanosti karakteristika gledalaca i televizijsko-medijskog uticaja. Prema Teoriji dvostepenog toka (Mek Kvin, 2000) može se zaključiti da je moguće da na publiku, u većoj meri od medija, utiču ugledni članovi grupe kojoj pripadaju iako je verovatno da je na njih neki medij već ostvario uticaj. Reč je o tome da se pretpostavlja 
da publika nije u tako pasivnom stanju i da zna trenutno da reaguje na društveno i politički značajne informacije dobijene putem televizije, čak i one iz vesti i emisije o aktuelnim događajima (Mek Kvin, 2000). Uprkos raznim teorijskim tumačenjima odnosa televizije i publike, brojna istraživanja su pokazala da informacije koje publika dobija putem televizije nisu jedine i ključne za njihovo doživljavanje stvarnosti, već da opšta slika uvek zavisi od kombinacije različitih perceptivnih uslova ili činilaca. Uostalom, „teorija aktivne publike oduvek je tvrdila da je publika pametnija i inventivnija nego što joj to pripisuju tradicionalne teorije komunikacije, kao i da može da bude veoma kreativna u načinu na koji odgovara na medije" (Džajls, 2011, str. 33).

Među onim faktorima koji imaju važnu ulogu u stvaranju odnosa prema stvarnosti pod dejstvom televizije često se spominju: nivo obrazovanja, pripadanje određenoj profesionalnoj sredini, kulturna, religiozna ili politička organizacija, krug prijatelja, društvena klasa ili celo društvo, etničke i nacionalne osobenosti (Severin i Tankard, 2000; Norris i Inglehart, 2009). Kako istraživanja rađena u Srbiji pokazuju, čak i na najjednostavniju obaveštenost građana utiču u velikoj meri njihova lična i socio-demografska obeležja, pa se efekti medija mogu tumačiti jedino uzimajući u obzir međudejstvo različitih faktora. U projektu čiji je cilj bio da utvrdi obrazovne efekte medija na publiku, rezultati su pokazali da su oni zavisili od nekoliko faktora: početnog stanja (znanja i stavova pre početka istraživanja), od sadržaja informacija, starosne dobi i zanimanja (Rakić, 1989).

\section{Televizijski sadržaji kao izvori znanja}

Televizijsko obrazovanje podvodi se pod različite forme obrazovanja, ali se o njemu najčešće govori kao o samoobrazovanju, situacionom i informalnom učenju (Oljača, 1992; Matijević, 2009). Nenamerno ili neintencionalno učenje predstavlja specifičnost obrazovanja putem televizije, ali može imati i karakteristike samoobrazovanja, što zavisi od toga da li odrasli ulaze svesno u taj proces ili se on odvija mimo njihove svesne obrazovne namere. Oljača (1992) navodi da se samoobrazovanje najčešće određuje kao vid učenja u kome dominira samoaktivnost odraslih; njegov rezultat su promene ličnosti, razvoj znanja, sposobnosti ili veština; u njima je naglašena samostalnost odraslih u određivanju cilja, planiranju, organizaciji, praćenju i vrednovanju uspešnosti procesa i rezultata tog procesa (Oljača, 1992, str. 59). Neki odrasli aktivno traže priliku da učenjem putem televizije razviju svoje kognitivne sposobnosti i znanja. To je naročito izraženo kada je reč o samousmerenom obrazovanju putem televizije koje se odnosi na učenje jezika, sadržaja iz 
nauke ili istorije (Grummell, 2010). Poter (2008) smatra da osobe s najvećim znanjem najviše i uče putem televizije. Prema njegovom mišljenju, publika sa širokim opštim znanjem je motivisana da dobije više informacija o različitim temama pa je u potrazi za medijima koji joj to mogu obezbediti.

Televizija spada među visokožanrovske medije i prema mišljenju Mek Kvina (2000) postoji relativno malo emisija u televizijskom repertoaru koje se ni bi mogle smestiti u neki od žanrova: sapunice, televizijske vesti, kvizovi, policijske serije, dokumentarni program, komedije (Mek Kvin, 2000).

Od svih pobrojanih žanrova, u informativnom gledaoci dobijaju najveći broj informacija. Analizom vesti može se pokazati da postoji ustaljena rutina i praksa u načinu prikazivanja događaja i vesti, u smislu njihove selekcije u odnosu na mnoštvo događaja koji se odigravaju u svetu (Fairclough, 1995, str. 86). Neka istraživanja o uticaju lokalnih medija na odrasle gledaoce pokazuju da su lokalni mediji značajniji od ostalih u učenju društvenih normi i ponašanja (Fleming i Thorson, 2008). S jedne strane, televizijske vesti utiču na informisanost i obaveštavanje gledalaca o događajima u svetu i u najvećoj meri su izvor znanja, a sa druge strane, selekcija vesti se povezuje sa informativno-ideološkom funkcijom televizije i s pravom se problematizuje.

Serije i sapunice su proizvodi popularne kulture koji uglavnom sa sobom nose negativnu konotaciju u pogledu izvora znanja. Međutim, nije retkost da su upravo serije zaslužne za stvaranje stereotipa; pomažu u sabiranju društvenih iskustava, u kategorizaciji, uopštavanju i organizaciji ogromnog broja informacija i predstavljaju izraz kognitivnih procesa (Ibroscheva i Ramaprasad, 2008). Žanrovi imaju mogućnost da pažnju odvuku u određenom pravcu, da upute ka zaključcima, isticanjem određenih intertekstualnih veza i semantičkih pretpostavki, što se u serijama ifilmovimačesto događa. U serijama se često u stereotipima na određen način prikazuju pripadnici različitih grupa: etničkih, nacionalnih, rasnih; na taj način konstruišu se i podstiču značenja i utiču na oblikovanje percepcije. Stereotipi su postali centralni koncept u učenju između grupa i u međukulturnim odnosima (Ibroscheva i Ramaprasad, 2008), a serije dobar kanal za njihovo prenošenje. Ovo nije isključivo karakteristika serija kao žanra, ona se odnosi i na ostale medije i žanrove, a u serijama zna da bude posebno izražena. Kosanović (2008) smatra da su filmovi i igrane televizijske serije u stanju da prenesu opšteprihvaćene kolektivne i kulturne stavove o raznim dimenzijama identiteta (Kosanović, 2008, str. 88). Serija kao žanr se više obraća ženskoj publici, obrađuje teme koje interesuju žensku publiku i računa na njihovu emotivnost, ali i otvara razgovor o temama koje su do tada predstavljale tabu. Na primeru serije Seks i grad i Očajne 
domaćice autorka pokazuje kako serije imaju moć da predstave sasvim novi identitet žena koji do tada nije tako jasno pokazivan. One prikazuju sasvim drugu perspektivu žena u četrdesetim od dotadašnje; žene imaju moć nad vlastitim životom i muškarcima i kao finansijski nezavisne predstavljaju novi ideal ženstvenosti (Kosanović, 2008, str. 92). Takođe, u ovim serijama se razgovara o mnogim problemima koji, kao što autorka kaže, možda mogu imati uticaja na način na koji će gledateljke razmišljati o svim tim otvorenim društveno i lično važnim pitanjima: o majčinstvu, prijateljstvu, romantičnim ljubavima, seksu, pobačaju, samohranom roditeljstvu, ženskim bolestima i o mnogim drugim važnim i manje važnim temama (Kosanović, 2008, str. 91). Serije, takođe, vrlo često problematizuju „društveno korisna” pitanja, ali se ta činjenica neretko minimizira. Za britanske serije je karakteristično da se bave društvenim problemima kao što su nezaposlenost, narkomanija, rasna pitanja, seksualnost (Mek Kvin, 2000, str. 55), čime se pokreću ova sporna pitanja i preko serija postaju izvor znanja o svetu koji nas okružuje, samo na jedan drugačiji način.

Kvizovi spadaju u takozvane takmičarske emisije i beleže veliku gledanost i popularnost. Često se prikazuju i kao programi koji se emituju u direktnom prenosu (mada to nije uvek slučaj), što doprinosi da ih gledaoci dožive na poseban način (Mek Kvin, 2000). Postoje razlike među njima u pogledu koncepcije tako da su neki više intelektualni, a neki više populistički (Clarke, 1987, prema: Mek Kvin, 2000), ali ih svejedno gledaoci veoma rado gledaju. Mek Kvin misli da su publici, u obrazovnom smislu, posebno privlačni upravo intelektualistički kvizovi koje smatra kvaziobrazovnim. Prema njegovom mišljenju, oni predstavljaju samo zabavu „prerušenu u intelektualno samouzdizanje" (Mek Kvin, 2000, str. 92). Kvizovi donose određene informacije, opšta znanja, površna znanja, besmislene, nevažne podatke i još mnogo boljih ili gorih informacija koje gledaoci očigledno povoljno vrednuju. Publika ih rado gleda verovatno zbog načina na koji je sam žanr organizovan i zbog pružanja mogućnosti gledaocima da i sami u igri učestvuju. U Srbiji je kviz kao žanr veoma popularan i beleži veliku zainteresovanost gledalaca (Senić, Josifović, 2009). Veću zainteresovanost od ostalih, za praćenje kvizova, pokazuju manje obrazovani, žene i mlađa publika (Senić, Josifović, 2009); gledaoci veruju da kviz ne predstavlja samo zabavu, već obrazovnu proveru i obrazovnu mogućnost. Među deset najgledanijih zabavnih televizijskih emisija u analiziranom četvorogodišnjem periodu, od 2003. do 2006. godine, na četiri televizijska kanala nalaze se dve vrste ovih emisija (Josifović ed., 2007). 
Dokumentarni program pripada žanru koji se u najvećoj meri posmatra kao dominantno obrazovni. Ta vrsta programa u prethodnom periodu, na svim televizijama, beležila je malu stopu gledanosti u odnosu na druge žanrove (Mek Kvin, 2000), tako da se često postavljalo pitanje njegove dalje televizijske proizvodnje i opstanka. Budući da televizijska produkcija beleži pojavu visokokvalitetnih dokumentarnih programa na popularnim televizijskim kablovskim kanalima, negativan trend u njihovoj popularnosti, $\mathrm{u}$ odnosu na ostale žanrove, polako se menja. Nasuprot serijama koje su igrane forme, gde je dominantan stereotipan način prikazivanja događaja, i čiju implicitnu obrazovnu poruku gledaoci mogu, ali ne moraju artikulisati, dokumentarni žanr je okrenut realizmu. U dokumentarnom programu pretenduje se na direktnu vezu sa realnim svetom (Mek Kvin, 2000), obrađuju se problemi „običnog” čoveka, prezentuju se istorijske činjenice i uopšte ceo koncept dokumentarnog programa je okrenut ka predstavljanju činjenica ${ }^{3}$. To doprinosi da gledaoci imaju utisak da je dokumentarni program kreiran da bi bio u funkciji povećanja znanja. Dokumentarni filmovi, jedna od formi dokumentarnog programa, imaju sličnosti sa nastavnim filmovima iz područja društvenih nauka jer su stvarani istim ili sličnim tehnikama dokumentarizma: rekonstrukcija događaja na bazi dramatizacije, beleženje događaja ili svedočenja učesnika prošlih događaja i slično (Zindović-Vukadinović, 1994). Upravo u tome, u beleženju događaja, svedočenju o njima i rekonstrukciji, je u najvećoj meri sadržan njegov obrazovni potencijal. Dokumentarni program je izvor autentičnog znanja baziran na događajima iz stvarnog života. On je, kako kaže Zindović-Vukadinović (1994), složen proizvod koji uključuje različite oblike angažovanja gledalaca. Razumevanje priče nije jedini cilj, iako je izuzetno važan, već i pobuđivanje emocionalnog učestvovanja: „Sama činjenica uhvaćeni život već govori o mogućnosti različitih interpretacija viđenog" (Zindović-Vukadinović, 1994, str. 97). U najvećoj meri zbog ovih svojstava dokumentarni program se više od svih ostalih doživljava kao obrazovni.

Film se pre svega mora posmatrati kao umetnost, ali se takođe može komentarisati iz pozicije teorije masovnih komunikacija kao medij masovne komunikacije. S obzirom na interesovanja koja su u središtu ovog rada i činjenice da je film veoma široka tema o kojoj se mnogo piše u kontekstu njegovih primarnih svojstava, umetničkih i estetskih, mi se na ovom mestu nećemo baviti tim njegovim karakteristikama. Namera je da naglasimo, da u

3 Ima različitih shvatanja o realnom predstavljanju događaja u dokumentarnim filmovima, prilozima i programima, ulozi montaže i drugih posebnih tehnika, ali s obzirom da to izlazi iz okvira naših istraživanja nećemo se upuštati u detaljniju analizu. 
filmskom umetničkom izrazu, upravo zbog specifičnosti koje ga karakterišu, postoji mogućnost dolaženja do izražaja njegovih obrazovnih i vaspitnih mogućnosti (Zindović-Vukadinović, 1994, str. 98). Kaže se da je sa stanovišta iznošenja činjenica dokumentarni film itekako pouzdaniji, ali sa stanovišta pobuđivanja afektivnog stanja igrani je u prednosti. Posmatrano sa pozicije obrazovanja i vaspitanja, u najširem smislu te reči, i dokumentarni i igrani filmovi su podjednako značajni jer se dodiruju i kognitivno i emocionalno (Zindović-Vukadinović, 1994, str. 98). Takođe, film predstavlja važno sredstvo u promovisanju društveno poželjnog ponašanja i često daje okvir za razumevanje i tumačenje važnih društvenih i političkih pitanja. Pojedini filmovi imali su snažan uticaj na problematizovanje važnih društvenih tema $\mathrm{i}$ često su bili u funkciji promocije određenih društvenih vrednosti. Na primer: film Misisipi u plamenu, dobitnik Oskara, reditelja Alena Parkera (1989) skrenuo je pažnju na položaj Afroamerikanaca u Americi; filmom Paklena pomorandža, reditelja Stenlija Kjubrika (1971), problematizovan je porast nasilja u društvu; filmom Milk, dobitnikom Oskara, reditelja Gusa Van Santa (2008), problematizovana je pojava diskriminacije na seksualnoj osnovi; film Nebo nad Berlinom, reditelja Vima Vendersa (1987), preko puno simbolike govori o ratu i o Berlinu, koji je iz njega u ožiljcima izašao; film Narod protiv Larija Flinta, reditelja Miloša Formana (1995), skrenuo je pažnju na slobodu štampe. Oslanjajući se na teoriju kulturnog delovanja, možemo reći da film predstavlja masovni medij pogodan za različite vrste delovanja na publiku, uključujući i predstavljanje putem stereotipa, socijalizaciju, potvrdu i reprodukciju ideologije (Mek Kvin, 2000, str. 246). To je slučaj i sa serijama, ali film ima veći autoritet i veću snagu uticaja.

\section{Metodološki okvir istraživanja}

Ovaj rad je deo doktorske disertacije „Odnos odraslih prema obrazovnoj i vaspitno-etičkoj funkciji televizije" i odabrano je da se (u tekstu koji sledi) prikaže jedan deo rezultata koji se odnose na povezanost pojedinih varijabli iz istraživanja. U nastavku će biti prikazana metodologija rada i objašnjenja prezentovanih varijabli.

Predmet istraživanja određen je kao odnos odraslih prema obrazovnoj i vaspitno-etičkoj funkciji televizije. S obzirom da je tema ovog rada obrazovna funkcija televizije, u daljem radu njena vaspitno-etička funkcija neće biti predmet diskusije. Shodno tome, može se reći da je obrazovna funkcija televizije posmatrana kroz odnos odraslih prema obrazovnim efektima koje sadržaji televizijskih emisija na njih ostvaruju. Cilj je dobiti odgovor na pitanje 
da li postoji, u kom stepenu i kakva je povezanost između karakteristika ispitanika i njihovog odnosa prema obrazovnoj funkciji televizije.

Karakteristike gledalaca su operacionalizovane kroz set nezavisnih varijabli: obrazovna obeležja odraslih i njihovo televizijsko-medijsko iskustvo.

Obrazovna obeležja ${ }^{4}$ ispitanika se odnose na: nivo prethodno stečenog obrazovanja i oblast bazičnog obrazovanja. U ovom radu, zbog ograničenosti prostora, biće predstavljeni rezultati koji se odnose samo na nivo prethodno stečenog obrazovanja. U istraživanju se pod nivoom prethodno stečenog obrazovanja podrazumevaju četiri stepena obrazovanja: osnovna škola, srednja škola, viša škola, fakultet i više.

Televizijsko-medijsko iskustvo predstavlja set varijabli u koje spadaju: televizijsko-medijski status ispitanika, izbor vrsta televizijskih stanica i vreme utrošeno u praćenju televizijskih programa. U okviru ovog seta varijabli odabrano je da se predstave rezultati koji se odnose na varijablu televizijsko-medijski status gledalaca. Varijabla status gledalaca obuhvata dve kategorije televizijskih gledalaca: medijske profesionalce i konzumente. Medijski profesionalci su gledaoci/ispitanici zaposleni u medijima, dok su konzumenti ispitanici bez radnog i profesionalnog medijskog iskustva.

Obrazovna funkcija televizije, kao zavisna varijabla, operacionalizovana je kroz četiri podvarijable: vrednovanje televizije kao izvora obrazovanja odraslih, sadržaj emisije kao izvor obrazovanja odraslih, način prezentovanja obrazovnih sadržaja i vreme emitovanja obrazovnih sadržaja. U radu će biti prikazana povezanost odabranih karakteristika odraslih gledalaca sa sledećim zavisnim varijablama: sadržaj emisije kao izvor obrazovanja odraslih, način prezentovanja obrazovnih sadržaja.

Varijablom sadržaj emisije kao izvor obrazovanja odraslih su obuhvaćeni svi sadržaji koji se mogu naći na repertoarima televizijskih stanica. Forma ili način na koji se prezentuju obrazovni sadržaji, predstavlja vrstu ili kategoriju medijskog proizvoda (Mek Kvin, 2000) ili kako se najčešće naziva - televizijski žanr. U istraživanje su uključeni sledeći žanrovi: dokumentarne emisije, film, serije i kviz.

Hipoteza glasi da postoji povezanost između karakteristika odraslih gledalaca i njihove procene obrazovne funkcije televizije.

U okviru ovog istraživanja primenjen je deskriptivni metod, odnosno neeksperimentalni, nekauzalni metod istraživanja.

4 Pojam obrazovna obeležja preuzet je i modifikovan za potrebe našeg istraživanja iz studije Kačavende-Radić (1989) - Slobodno vreme i obrazovanje. 
Od tehnika za prikupljanje podataka koristili smo anketiranje i skaliranje. Osnovni merni instrument je baterija instrumenata, upitnik i više skala (petostepena i sedmostepena deskriptivna skala, skala rangova i grafička skala sudova) koje su posebno konstruisane za ovo istraživanje.

Našim istraživanjem, koristeći prigodan uzorak, obuhvaćen je ukupno 421 ispitanik. Ukupan uzorak čine gledaoci televizijskog programa, konzumenti - bez profesionalnog radnog iskustva u medijima (247 odraslih konzumenata, gledalaca televizijskog programa) i medijski profesionalci, zaposleni na televiziji (novinari, producenti, montažeri, kamermani, organizatori i sl.) i u drugim medijima (ovaj uzorak činilo je 174 ispitanika, najvećim delom zaposlena, sa televizijskom ili nekom drugom vrstom medijskog iskustva).

Istraživanje je sprovedeno u julu i avgustu mesecu 2010. godine na teritoriji Beograda.

S obzirom na to da ukupan uzorak čine televizijski gledaoci koji predstavljaju i medijske profesionalce i konzumente, oni su kao celovit uzorak tretirani u obradi podataka.

Prema istraživanjima i merenjima gledanosti televizijskih stanica za period kraja 2009. i početak 2010. godine (AGB Nielsen Media Research Serbia) sledeće nacionalne televizijske stanice su se izdvojile kao najgledanije: RTS, Pink, Foks, Avala, Studio B. Međutim, s obzirom na karakter televizije, veliku ponudu kablovskih operatera i brojnih programa koji su dostupni gledaocima, nismo se ograničili samo na najgledanije televizijske stanice sa nacionalnom pokrivenošću, već i na kompletnu televizijsku ponudu. Televizijske stanice razvrstali smo prema kriterijumu dominantne zastupljenosti određene vrste sadržaja na osnovu čega se vrši njihova profilacija. Tako smo izdvojili televizijske stanice pretežno informativnog (većinom domaći i strani javni servisi), zabavnog (većinom komercijalne televizije zabavnog programa), obrazovnog (većinom domaće i inostrane televizijske emisije dokumentarnog, naučnog i obrazovnog programa) i sportskog karaktera (domaće i inostrane televizijske stanice sportskog programa).

\section{Rezultati istraživanja}

S obzirom na ograničenost prostora, prikazaćemo najznačajnije rezultate koji se odnose na korelaciju izdvojenih varijabli. Na ovom mestu biće prikazan i deo rezultata istraživanja koji se odnosi na povezanost sadržaja i načina prezentovanja televizijskih sadržaja sa nivoom obrazovanja i televizijskomedijskim statusom gledalaca. 


\section{Sadržaj televizijskih emisija i nivo obrazovanja}

U Tabeli 1 prikazan je odnos između sadržaja televizijskih emisija i nivoa obrazovanja ispitanika. Potrebno je napomenuti da je nivo obrazovanja meren obrazovnim postignućem $u$ formalnom sistemu obrazovanja. Iako smo svesni činjenice da on ne predstavlja osnovni i jedini kriterijum znanja, ovaj način je odabran radi njegove lakše kvantifikacije. Podaci pokazuju da nivo obrazovanja predstavlja varijablu koja korelira sa procenom obrazovne vrednosti televizijskih sadržaja i to: dokumentarnih emisija ( $\mathrm{r}=0,196$, $\mathrm{p}<0.01)$, emisija iz kuture i umetnosti $(\mathrm{r}=0,167, \mathrm{p}<0.01)$, emisija iz nauke $\mathrm{i}$ o popularnoj nauci $(\mathrm{r}=0,262, \mathrm{p}<0.01)$, obrazovnih emisija $(\mathrm{r}=0,175, \mathrm{p}<0.01)$, zabavnih i komercijalnih sadržaja $(\mathrm{r}=-0,195, \mathrm{p}<0.01$ i $\mathrm{r}=-0,129, \mathrm{p}<0.01)$. Dobijene vrednosti kreću se u rasponu od $\mathrm{r}=-0,129, \mathrm{p}<0.01$ do $\mathrm{r}=0,262$, $\mathrm{p}<0.01$ a najveća povezanost procene sadržaja televizijskih emisija prema nivou obrazovanja je sa emisijama iz nauke i o popularnoj nauci $(\mathrm{r}=0,262$, $\mathrm{p}<0.01$ ). Kao korelacioni koeficijent korišćen je Pirsonov koeficijent produktmoment korelacije (r). Raspon od $\mathrm{r}=-0,129$ do $\mathrm{r}=0,262$ predstavlja nisku povezanost dveju varijabli. Međutim, ona je statistički značajna na nivou 0,01 i nivou 0,05 , što znači da sa $99 \%$ odnosno $95 \%$ možemo biti sigurni da će se dobijeni nalazi ponoviti i u populaciji. Nivo obrazovanja statistički značajno ne korelira sa informativnim, verskim, religijskim i sportskim emisijama.

\section{Tabela 1.: Povezanost procene obrazovne vrednosti televizijskih sadržaja $i$ nivoa obrazovanja ispitanika}

\begin{tabular}{|l|l|}
\hline Televizijski sadržaji & Nivo obrazovanja \\
\hline Informativni program &,- 035 \\
\hline Dokumentarni program & $\mathbf{1 9 6}(* *)$ \\
\hline Kulturno - umetnički program & $\mathbf{1 6 7}(* *)$ \\
\hline Verski i religijski program &, 052 \\
\hline Naučni program & $\mathbf{2 6 2 ( * * )}$ \\
\hline Obrazovni program & $\mathbf{1 7 5}(* *)$ \\
\hline Zabavni program & $-\mathbf{1 9 5}(* *)$ \\
\hline Sportski program &,- 030 \\
\hline Komercijalni program & $\mathbf{- , 1 2 9}(* *)$ \\
\hline
\end{tabular}

** Statistička značajnost na nivou 0.01

* Statistička značajnost na nivou 0.05 
Osnovni zaključak je da visokoobrazovani odrasli gledaoci televizijske sadržaje koji spadaju u dominantno obrazovni korpus procenjuju kao emisije visokoobrazovnog potencijala, dok gledaoci nižeg formalnog obrazovanja značajnije vrednuju emisije zabavnog karaktera.

Naime, programi iz oblasti kulture, obrazovanja ili umetnosti zbog implicitno obrazovnog značenja koje u sebi nose, po automatizmu se mogu doživljavati kao pogodni za sticanje znanja. Međutim, prema ovim podacima ipak vidimo da obrazovanje ima ulogu u formiranju takve percepcije. To znači da viši obrazovni nivo ispitanika podrazumeva višu procenu i vrednovanje obrazovne značajnosti navedenih emisija. Suprotan nalaz se dobija kada se procena odnosi na televizijske zabavne i komercijalne programe. Što je niži nivo obrazovanja ispitanika to je njihova percepcija obrazovne vrednosti zabavnih i komercijalnih sadržaja viša.

U prilog ovim nalazima idu podaci dobijeni istraživanjem koje je izvršio Centar RTS-a za istraživanje javnog mnjenja, programa i auditorijuma (Senić i Josifović, 2009). Podaci iz tog istraživanja se odnose na programske afinitete gledalaca televizije i korespondiraju sa našim rezultatima. Osnovni nalaz je da među gledaocima postoji relativno ujednačeno interesovanje za određene vrste programa. Ipak, ono je najveće za obrazovno-naučni program i za njega su najviše zainteresovani gledaoci višeg nivoa obrazovanja. Od ukupnog procenta zainteresovanih, gledaoci sa završenim fakultetom, procentualno gledano, u najvećoj meri imaju izražen afinitet za:

- Obrazovno-naučni program - $(87,4 \%)$,

- dokumentarni program - (78,9\%),

- $\quad$ program iz kulture i umetnosti-(67,8\%).

$\mathrm{U}$ pomenutom istraživanju merila se zainteresovanost gledalaca za određeni vid programa, ali logično da se afiniteti temelje na bazi njihove pozitivne procene obrazovne vrednosti tih programa. Mek Kvin (2000) kaže da dokumentarni programi pripadaju tom, kako smo ih nazvali, dominantno obrazovnom korpusu sadržaja i privlače specifičnu publiku, onu višeg obrazovanja. To nikako ne znači da samo obrazovani ljudi gledaju dokumentarni program, što i naši podaci potvrđuju.

Poter (2008) u knjizi Medijska pismenost navodi da su viši nivo znanja i veće iskustvo činioci od kojih zavisi na koji način će gledaoci procenjivati i razumeti televizijske poruke i kako će informacije i znanja koja tim putem dobijaju upotrebiti. U skladu s tim, moglo bi se reći da postoji potreba ljudi sa višim obrazovanjem za negovanjem obrazovanja i traženje najpogodnijih kanala putem kojih je te potrebe moguće zadovoljiti. To bi značilo da: 
- televizijska publika višeg formalnog obrazovanja jednostavnije i lakše prepoznaje i pronalazi kanale putem kojih će moći da zadovolji obrazovno-kulturne potrebe,

- publika višeg formalnog obrazovanja televiziju prepoznaje kao jedan od tih kanala ili mogućnosti za učenje.

Verujemo da je lakše publici višeg nivoa obrazovanja da zaključi šta predstavlja dostupnu obrazovnu mogućnost, čak i kada ona nije predstavljena eksplicitno, u formi koja na to nedvosmisleno ukazuje. Oni to mogu bolje uočiti od publike nižeg obrazovanja. Moguće da publika nižeg formalnog obrazovanja u većoj meri televiziju doživljava kao zabavu ne razumevajući ili ne razmišljajući da li su ti sadržaji pogodni za učenje i obrazovanje.

\section{Sadržaj televizijskih emisija i status gledalaca}

Ispitanici se razlikuju u pogledu njihovog televizijsko-medijskog statusa, odnosno da li su profesionalno i radno aktivni u medijima ili nisu. Prema tom kriterijumu, podelili smo ih na medijske profesionalce (zaposlene u medijima) i konzumente (bez profesionalnog televizijsko-medijskog iskustva). Podaci koji su prikazani u Tabeli 2 odnose se na razlike između medijskih profesionalaca i konzumenata u proceni obrazovne vrednosti televizijskih sadržaja.

Tabela 2.: Razlika medu statusom gledalaca po pitanju obrazovne vrednosti televizijskih sadrăaja

\begin{tabular}{|c|c|c|c|c|c|c|}
\hline \multicolumn{2}{|c|}{ Televizijski sadržaji } & $\begin{array}{c}\text { Medijski } \\
\text { profesionalci }\end{array}$ & Konzumenti & $\mathbf{F}$ & Značajnost & Eta \\
\hline \multirow{2}{*}{$\begin{array}{l}\text { Informativni } \\
\text { program }\end{array}$} & $\mathbf{A S}$ & 3,92 & 3,63 & \multirow{2}{*}{2,47} & \multirow{2}{*}{, 117} & \multirow{2}{*}{,077 } \\
\hline & SD & 1,85 & 1,90 & & & \\
\hline \multirow{2}{*}{$\begin{array}{l}\text { Dokumentarni } \\
\text { program }\end{array}$} & $\mathbf{A S}$ & 5,25 & 5,05 & \multirow{2}{*}{1,24} & \multirow{2}{*}{,265 } & \multirow{2}{*}{, 054} \\
\hline & SD & 1,70 & 1,90 & & & \\
\hline \multirow{2}{*}{$\begin{array}{l}\text { Kulturno- } \\
\text { umetnički } \\
\text { program }\end{array}$} & $\mathbf{A S}$ & 5,34 & 5,21 & \multirow{2}{*}{, 522} & \multirow{2}{*}{, 471} & \multirow{2}{*}{, 035} \\
\hline & SD & 1,73 & 1,87 & & & \\
\hline \multirow{2}{*}{$\begin{array}{l}\text { Verski i } \\
\text { religijski } \\
\text { program }\end{array}$} & $\mathbf{A S}$ & 3,91 & 4,01 & \multirow{2}{*}{,249 } & \multirow{2}{*}{, 618} & \multirow{2}{*}{, 024} \\
\hline & SD & 1,96 & 2,14 & & & \\
\hline \multirow{2}{*}{$\begin{array}{l}\text { Naučni } \\
\text { program }\end{array}$} & $\mathbf{A S}$ & 5,48 & 5,28 & \multirow{2}{*}{1,11} & \multirow{2}{*}{,291 } & \multirow{2}{*}{, 052} \\
\hline & SD & 1,57 & 2,04 & & & \\
\hline
\end{tabular}




\begin{tabular}{|l|l|l|l|l|l|l|}
\hline $\begin{array}{l}\text { Obrazovni } \\
\text { program }\end{array}$ & AS & 5,33 & 5,07 & 1,84 &, 175 &, 066 \\
\hline Zabavni & SD & 1,70 & 2,10 & & & \\
program & AS & 2,41 & 3,04 & 10,8 &, $\mathbf{0 0 1}$ &, 159 \\
\hline Sportski & AS & 1,76 & 2,06 & & & \\
program & SD & 2,97 & 3,66 & 11,5 &, 001 &, 164 \\
\hline $\begin{array}{l}\text { Komercijalni } \\
\text { program }\end{array}$ & AS & 1,72 & 2,23 & & & \\
\hline
\end{tabular}

Jednofaktorskom analizom varijanse dobijeni su rezultati koji pokazuju da medijski profesionalci i konzumenti veoma slično procenjuju obrazovnu vrednost sadržaja koji se emituju na televiziji. Jedine statistički značajne razlike između ove dve grupe postoje kada je u pitanju procena obrazovne vrednosti sportskih i zabavnih emisija. Medijski profesionalci u nešto većoj meri od konzumenata smatraju da sportske $(\mathrm{AS}=3,66)$ i zabavne $(\mathrm{AS}=3,04)$ emisije imaju obrazovni karakter. Statistička značajnost je na nivou 0,01. Medijski profesionalci, prirodom posla bolje razumeju medije, način njihovog funkcionisanja i puteve kojima se efekti na publiku ostvaruju. To znači da imaju profesionalna znanja na osnovu kojih zaključuju da je obrazovanje putem televizije moguće ne samo putem eksplicitno obrazovnih već i ostalih sadržaja koji se putem televizije emituju.

\section{Način prezentovanja obrazovnih sadržaja}

Ispitanici su imali zadatak da izvrše rangiranje ponuđenih televizijskih programa (i televizijskih žanrova) koji su prikazani u tabeli broj 3. Od ispitanika je traženo da rangiraju koji od ponuđenih televizijskih formi (oblika) ima najbolji obrazovni karakter, pri čemu je dobijen sledeći statistički nalaz:

Tabela 3.: Prosečan rang televizijskih formi prema obrazovnoj vrednosti

\begin{tabular}{|l|c|c|c|}
\hline Način prezentovanja obrazovnih sadržaja & Rang & AS & SD \\
\hline Dokumentarni program & $\mathbf{1}$ & 2.97 & 1.27 \\
\hline Film & $\mathbf{2}$ & 2.60 & .840 \\
\hline Kviz & $\mathbf{3}$ & 2.56 & 1.06 \\
\hline Serija & $\mathbf{4}$ & 1.85 & .931 \\
\hline
\end{tabular}

Podaci iz tabele nas upućuju na opšti zaključak da percepcija ispitanika govori o tome da je dokumentarni program najbolji način za prenošenje 
obrazovnih sadržaja, odnosno da je njegova obrazovna vrednost najveća. Film je na drugom mestu po obrazovnoj vrednosti, a dalje ih slede kvizovi i serije. Moguće objašnjenje za ovakav nalaz može biti u percepciji ispitanika o „ozbiljnosti” dokumentarnih programa koji, kao takvi, treba da služe obrazovanju. Tako se doživljavaju kao najbolji način prenošenja obrazovnih sadržaja. Takođe, može se pretpostaviti da gledaoci u filmovima, posebno onim koji spadaju u istorijske, biografske, autobiografske i slično, vide dobar način za obrazovanje. Ekranizovanje književnih dela ili istorijskih događaja mogu doživeti kao pogodan način za proširivanje obrazovanja. Kvizovi i serije, generalno, predstavljaju popularne televizijske forme i gledaoci ih doživljavaju kao obrazovnu mogućnost, ali su u ovoj kombinaciji ponuđenih formi niže rangirani od ostalih.

\section{Način prezentovanja obrazovnih sadrăaja i nivo obrazovanja}

Tabela 4.: Povezanost načina prikazivanja televizijskih sadržaja i nivoa obrazovanja

\begin{tabular}{l|l} 
Način prezentovanja obrazovnih sadržaja & Nivo obrazovanja \\
\hline Dokumentarni &, $257(* *)$ \\
\hline Film &,- 063 \\
\hline Serija &,$- 124(*)$ \\
\hline Kviz &,$- 148(* *)$
\end{tabular}

** Statistička značajnost na nivou 0.01

* Statistička značajnost na nivou 0.05

Varijabla nivo obrazovanja, kao i kod sadržaja, izdvojila se kao faktor koji u najvećoj meri determiniše procenu obrazovne vrednosti pojedinih formi, odnosno načina prezentovanja televizijskih sadržaja. Podaci nam govore o tome da publika višeg nivoa formalnog obrazovanja u većoj meri procenjuje da je dokumentarni program najbolji vid prenošenja obrazovnih sadržaja $(\mathrm{r}=0,257, \mathrm{p}<0.01)$, a istovremeno ispitanici formalno nižeg obrazovnog nivoa misle da su kvizovi $(\mathrm{r}=-0,148, \mathrm{p}<0.01)$ i serije $(\mathrm{r}=-0,124, \mathrm{p}<0.05)$ bolji načini putem kojih se moguće obrazovati. Ne postoji statistički značajna povezanost između formalnog nivoa obrazovanja i filma. Svi ispitanici bez obzira na formalno obrazovanje slično procenjuju njegovu pogodnost za prenošenje obrazovnih sadržaja.

Kao što su rezultati već pokazali, dokumentarni program ipak privlači određenu publiku (Mek Kvin, 2000), a prema našim podacima ta određenost 
publike nalazi se upravo u obrazovanju. Publika višeg nivoa formalnog obrazovanja preferira prikazivanje obrazovnih emisija u dokumentarnoj formi. Neka skorija slična istraživanja u rezultatima se poklapaju sa našim. Naime, u istraživanju o predstavljanju nauke i naučnih istraživanja na televiziji, objavljenom u Eurobarometru pod pokroviteljstvom Evropske komisije (Special Eurobarometar, 2007) ${ }^{5}$, nađeno je da: Evropljani vole da gledaju dokumentarne filmove o naučnim istraživanjima, da većina stanovnika Evropske unije misli da su dokumentarne emisije najbolja forma prikazivanja naučnih sadržaja i da građani zemalja Beneluksa, koji najviše ulažu u naučna istraživanja, favorizuju dokumentarni način prikazivanja emisija. I u tom istraživanju je dobijen podatak da najobrazovanijem delu publike više odgovara dokumentarni način predstavljanja naučnih sadržaja. Očigledno, viši stupanj obrazovanja pretpostavlja sofisticiraniji ukus i interesovanja koja je moguće predstaviti u formi pogodnoj za tu vrstu sadržaja pa se zato ta vrsta programa često proglašava elitističkom (Mek Kvin 2000).

Kvizovi i serije su žanrovi koji okupljaju najrazličitiju publiku i imaju veliku gledanost. Prema našim podacima, prednost im daju gledaoci nižeg nivoa obrazovanja. Verujemo da kvizovi privlače niže obrazovanu publiku, koja ih percipira kao emisije veće obrazovne vrednosti, jer im daju mogućnost da dožive sebe kao ravnopravne učesnike u nekom značajnom obrazovnom procesu. Mek Kvin (2000) takođe tvrdi da među publikom koja voli kvizove postoji određena diferencijacija na temelju njihovih obrazovnih karakteristika. Tako, kvizovi u kojima nagrade nisu u prvom planu, u obrazovnom smislu bolje kotiraju, kao što je slučaj sa takozvanim intelektualnim kvizovima (Mek Kvin, 2000, str. 92). Tu ima, kako Mek Kvin kaže, lažnog intelektualizma, pa se gledaoci kojima populistički kviz deluje vulgarno opredeljuju za „zabavu prerušenu u intelektualno samouzdizanje" (ibid., str. 92). U istraživanju iz 2009. godine o programskim afinitetima gledalaca televizije (Senić i Josifović, 2009) gledaoci su pokazali značajno interesovanje za kvizove: $61,7 \%$. Najveće interesovanje za ove emisije bilo je među gledaocima iz unutrašnjosti Srbije, a kako podaci govore, iznad proseka su im naklonjeni gledaoci sa nezavršenom i završenom osnovnom i srednjom školom.

Slična situacija je i sa serijama; one su veoma gledane i privlače najrazličitiju publiku. Kako vidimo, gledaoci nižeg formalnog obrazovanja im daju više obrazovne vrednosti smatrajući ih korisnim za učenje. Prema već pominjanom istraživanju (Senić i Josifović, 2009) domaće serije beleže veću

5 Eurobarometar je zbirni naziv za istraživanja koja Evropska komisija sprovodi u državama članicama kako bi pratila javno mnjenje građana EU o EU, zatim o proširenju, društvenim prilikama, zdravstvu, kulturi, zaštiti okoline, evru, odbrani itd. 
gledanost nego strane $(62,8 \%)$ i za njih su u najvećoj meri zainteresovani stariji gledaoci sa nezavršenom i završenom osnovnom i srednjom školom. Zainteresovanost za strane serije se ne razlikuje značajno među gledaocima u pogledu stepena obrazovanja. Serije, kao što drugi autori primećuju, mogu imati obrazovnu vrednost, mogu se baviti problemima sa kojima se suočava društvo, problemima delinkvencije, narkomanije, statusa imigranata, mode, rodne ravnopravnosti, emancipacije žena i slično, i mogu pokrenuti neka važna društvena pitanja (Mek Kvin, 2000; Grdešić, 2006; Lemiš, 2008; Kosanović, 2008; Peruško, 2011). Međutim, prema našim podacima, čini se da ih publika višeg formalnog obrazovanja nije prepoznala na taj način. Doduše, u toku istraživanja u razgovoru sa ispitanicima dobili smo interesantna zapažanja upravo u vezi s obrazovnim potencijalom serija. Neki ispitanici imali su potrebu da prokomentarišu kako se ne obraća dovoljno pažnje na ono što su serije u obrazovnom smislu prouzrokovale kod publike, pri tome konkretno navodeći obrazovne efekte kao što su: povećano interesovanje gledatelja za učenje španskog jezika (pod uticajem latinoameričkih serija), identifikovanje žena - u pozitivnom emancipatorskom smislu - sa glavnim junakinjama kultne serije „Seks i grad”, učenje o nekim običajima iz ranijeg istorijskog perioda Srbije (neke domaće serije) i slično. Ipak, takvi stavovi se nisu ispoljili u rezultatima koji se odnose na publiku višeg formalnog obrazovanja. Mislimo da većina publike serije povezuje sa, vrlo često, njihovim niskim kvalitetom u produkcijskom smislu i svesna je široko rasprostranjenog stava da je praćenje serija odlika ljudi nižeg društvenog statusa. U tom smislu, moguće je da su ispitanici davali odgovore koji su na liniji društveno poželjnih.

Na ovom mestu zapažamo jednu pojavu koja ima tendenciju ponavljanja i izražena je u okolnosti da niže obrazovani gledaoci, u zavisnosti od toga koji televizijski program prate, u većoj meri upravo tom programu daju i najveću obrazovnu vrednost (ispoljila se, takođe, $u$ rezultatima vezanim za ispitivanje povezanosti sadržaja i nivoa obrazovanja). Tako, niže obrazovani gledaoci u većoj meri gledaju serije i sa tim u vezi ih obrazovno pozitivno vrednuju.

Prema rezultatima rangiranja televizijskih formi za prikazivanje obrazovnih sadržaja film se izdvojio kao najbolji. Međutim, kada je u pitanju njegova povezanost sa nivoom obrazovanja gledalaca, nije nađena statistički značajna povezanost.

\section{Način prezentovanja obrazovnih sadržaja i status gledalaca}

Podaci iz Tabele 5 odnose se na razliku u percepciji medijskih profesionalaca i konzumenata $\mathrm{u}$ vezi s najpogodnijim načinom prezentovanja obrazovnih sadržaja: 
Tabela 5.: Razlike između medijskih profesionalaca $i$ konzumenata po pitanju načina prezentovanja obrazovnog sadržaja

\begin{tabular}{|c|c|c|c|c|c|c|}
\hline \multicolumn{2}{|c|}{$\begin{array}{l}\text { Način prezentovanja } \\
\text { obrazovnog sadržaja }\end{array}$} & \multirow{3}{*}{\begin{tabular}{|c|}
$\begin{array}{c}\text { Medijski } \\
\text { profesionalci }\end{array}$ \\
3,2299 \\
1,15505 \\
\end{tabular}} & \multirow{3}{*}{$\begin{array}{c}\text { Konzumenti } \\
2,8016 \\
1,33020\end{array}$} & \multirow{3}{*}{$\begin{array}{r}\text { F } \\
11,77\end{array}$} & \multirow{3}{*}{\begin{tabular}{|} 
Značajnost \\
, 001
\end{tabular}} & \multirow{3}{*}{$\begin{array}{l}\text { Eta } \\
, 165\end{array}$} \\
\hline \multirow{2}{*}{ Dokumentarni } & AS & & & & & \\
\hline & SD & & & & & \\
\hline \multirow{2}{*}{ Film } & AS & 2,5632 & 2,6356 & \multirow{2}{*}{,758 } & \multirow{2}{*}{,385 } & \multirow{2}{*}{, 042} \\
\hline & SD &, 82169 &, 85351 & & & \\
\hline \multirow{2}{*}{ Serija } & AS & 1,8161 & 1,8907 & \multirow{2}{*}{ 654 } & \multirow{2}{*}{,419 } & \multirow{2}{*}{039} \\
\hline & SD & ,93770 & ,92843 & & & \\
\hline \multirow{2}{*}{ Kviz } & AS & 2,4023 & 2,6842 & \multirow{2}{*}{7,245} & \multirow{2}{*}{,007 } & \multirow{2}{*}{, 130 } \\
\hline & SD & 1,05304 & 1,06184 & & & \\
\hline
\end{tabular}

Za ispitivanje razlika između medijskih profesionalaca i konzumenata po pitanju načina prezentovanja obrazovnog sadržaja korišćena je analiza varijanse (ANOVA). Dobijene su statistički značajne razlike na nivou 0,01 i 0,05 .

Statistički značajne razlike postoje u pogledu vrednovanja najboljeg načina prezentovanja obrazovnih sadržaja između ove dve grupe ispitanika. Oni se ne slažu u pogledu vrednovanja načina predstavljanja obrazovnih programa putem dokumentarnog programa i kvizova. Medijski profesionalci, za razliku od konzumenata, veću vrednost za prenošenje obrazovnih sadržaja daju dokumetarnoj formi $(\mathrm{AS}=3,22)$. Konzumenti, nasuprot tome, bolje od medijskih profesionalaca vrednuju kviz $(\mathrm{AS}=2,68)$. Nisu se pokazale statistički značajne razlike između ove dve grupe na ostalim kategorijama (film i serija).

Jedno od objašnjenja za ovaj podatak može biti, kao i u prethodnom slučaju, vezan za viši obrazovni nivo medijskih radnika u odnosu na konzumente (posmatrajući strukturu uzorka) i njihova znanja o karakteristikama i funkcionisanju televizijskih formi. Otuda mogu poticati i razlike među ispitanicima u proceni obrazovnog potencijala dokumentarne televizijske forme. Drugi razlog može biti rasprosranjenost mišljenja među konzumentima (stereotipi) da su dokumentarne emisije nedinamične, a kvizovi zanimljivi, pa je zbog te karakteristike kvizova putem njih moguće više i brže učiti. 


\title{
Zaključna razmatranja
}

$\mathrm{Na}$ osnovu predstavljenih rezultata i diskusije može se zaključiti da postoji povezanost između karakteristika odraslih gledalaca i njihove procene obrazovne funkcije televizije. Zaključak je da pozitivan odnos prema obrazovnoj vrednosti televizijskih sadržaja raste sa višim nivoom obrazovanja, posebno kada se procena odnosi na programe putem kojih se emituju naglašeno obrazovni sadržaji (dokumentarni, kulturno-umetnički, naučni i obrazovni). Televizijska publika višeg formalnog obrazovanja, upravo zbog znanja koje poseduje, jednostavnije i lakše prepoznaje i pronalazi kanale putem kojih će moći da zadovolji obrazovno-kulturne potrebe i televiziju prepoznaje kao jedan od tih kanala ili mogućnosti za učenje. Takođe, može se zaključiti da je nivo formalnog obrazovanja faktor od koga zavisi vrednovanje najpogodnijih formi za prikazivanje obrazovnih sadržaja.

$\mathrm{Na}$ osnovu rezultata zaključili smo da postoje razlike između medijskih profesionalaca i konzumenata $u$ odnosu na procenu obrazovne i vaspitnoetičke funkcije televizije i one predstavljaju izraz involviranosti medijskih profesionalaca u rad medija. Naime, medijski profesionalci, zbog posla kojim se bave, bolje razumeju medije, način njihovog funkcionisanja i puteve kojima se medijski efekti na publiku ostvaruju. To znači da imaju profesionalna znanja na osnovu kojih zaključuju da je obrazovanje putem televizije moguće ne samo preko eksplicitno obrazovnih već i ostalih sadržaja koji se putem televizije emituju.

\section{CHARACTERISTICS OF ADULTS AS FACTORS IN EVALUATION OF EDUCATIONAL FUNCTION OF TELEVISION}

\begin{abstract}
- Abstract -
This paper proceeds from the assumption that educational features and television-media experience of adults determine their view regarding the educational function of the television. The study wants to get an answer to the question whether there is, to what degree and what is the connection between certain characteristics of respondents and their relation to the educational function of the television. The results showed that the level of education is a factor in the assessment of educational functions of television,
\end{abstract}


and a positive attitude towards the educational value of television content increases with higher levels of education. It has been shown that the level of formal education is a determinant of evaluating the most appropriate form of presentation of educational content. Also, the results suggest the conclusion that the television-media status of spectators is a significant factor of the educational function of television assessment.

Keywords: adult education, television, media, media education.

\section{Literatura}

- Džajls, D. (2011). Psihologija medija. Beograd: Clio.

- Fairclough, N. (1995). Media Discourse. London: Edward Arnold.

- Fleming, K. i Thorson, E. (2008). Assessing the Role of InformationProcessing Strategies in Learning From Local News Media About Sources of Social Capital. Mass Communication and Society. Vol. 11. No 4. str. 398-419. [Internet] Dostupno na: http://www.tandfonline. com/doi/full/10.1080/15205430801950643.

- Grdešić, M. (2006). Seks i grad - (a)političnost ženskih žanrova. Hrvatski filmski ljetopis. br. 46., str. 32-42.

- Grummell, B. (2010). Filtering informal learning in everyday life: invoking ordinariness and moving to civic engagement. International Journal of Lifelong Education. Vol 29, No. 5. str. 565-579. [Internet] Dostupno na: http://www.tandfonline.com/doi/full/10.1080/0260137 0.2010 .512805 .

- Ibroscheva, E. i Ramaprasad, J. (2008). Do media matter?: A social construction model of stereotypes of foreigners. Journal of Intercultural Communication, issue 16. [Internet] Dostupno na: http://www.immi.se/intercultural/.

- Josifović, S. ed. (2007). Strukturalna obeležja auditorijuma TV programa od 2004-2007. Beograd: RTS - Centar za istraživanje javnog mnjenja, programa i auditorijuma.

- Katz, E. i Lazarsfeld, P. (1956). Personal Influence. Glencoe. The Free Press.

- Kosanović, S. (2008). Suvremene muško-ženske konstrukcije u američkim televizijskim serijama Seks i grad, Kućanice $i$ Vatreni dečki. Medijska istraživanja. god. 14, br.2, str. 87-102. 
- Lemišs, D. (2008). Deca i televizija. Beograd: Clio.

- Matijević, M. (2009). Informalno učenje odraslih u novom (multi) medijskom okruženju. Andragoški glasnik. vol.13, no 2. str.105-111.

- Mek Kvin, D. (2000). Televizija. Beograd: Clio. 